\title{
The Political Attitudes and Subjective Wellbeing of the One Percent
}

\author{
Nikhil K. Sengupta ${ }^{1}$ (D) . Chris G. Sibley ${ }^{2}$
}

Published online: 8 October 2018

(c) The Author(s) 2018

\begin{abstract}
In capitalist societies, individuals who occupy the highest positions in the economic hierarchy feature prominently in the political discourse under the moniker of the One Percent. However, little is known about how the psychology of One Percent might differ from that of the average person. Using a large, nationally representative sample in New Zealand $(N=14,650)$, we aimed to fill this gap examining the political attitudes and subjective wellbeing of the top one percent of the income distribution. We found that, compared to general public, the One Percent in New Zealand more strongly legitimize the political and economic systems in society, and express lower support for redistributive taxation. They also report higher life satisfaction, self-esteem and belongingness compared to everyone else. Thus, the One Percent benefit not only economically and politically from the current system, but also psychologically. Moreover, their political beliefs serve to bolster the inequality from which they benefit.
\end{abstract}

Keywords Inequality $\cdot$ One Percent $\cdot$ Political attitudes $\cdot$ Subjective wellbeing

"We are the 99\%"- the rallying cry of the Occupy Wall Street movement-was a call for society to unite against the disproportionate power of a small group of economic elites: The One Percent (Occupy Wall Street 2011). This moniker of the One Percent has now entered the lexicon and become a prominent feature of the political discourse on inequality in Western democracies (e.g., The Equality Trust 2017; Carroll and Kertscher 2016). The people to whom this label is applied are argued to be using their influence to bend policy to their own ends, subverting the democratic process (e.g., Stilgitz 2011).

However, these arguments are currently being made in the absence of data about the how the political psychology of individuals that constitute this group might differ from that of the average person. We know very little about how the One Percent view the political and economic systems under which they live, or how they feel about redistributive policies designed to reduce inequality. These are important gaps because claims

Nikhil K. Sengupta

nikhil.sengupta@psy.ox.ac.uk

1 Department of Experimental Psychology, University of Oxford, South Parks Rd, Oxford OX1 3UD, UK

2 School of Psychology, University of Auckland, Auckland, New Zealand 
Table 1 The One Percent in New Zealand and around the world Source: World Inequality Database (2018)

\begin{tabular}{llll}
\hline Country & $\begin{array}{l}\text { Income thresh- } \\
\text { old (USD) }\end{array}$ & $\begin{array}{l}\text { Average } \\
\text { income (USD) }\end{array}$ & $\begin{array}{l}\text { Share of total } \\
\text { income (\%) }\end{array}$ \\
\hline USA & 283,749 & 869,175 & 20.4 \\
UK & 168,678 & 393,957 & 13.9 \\
Australia & 182,185 & 360,163 & 9.1 \\
New Zealand & $\mathbf{1 4 7 , 7 0 5}$ & $\mathbf{2 5 4 , 4 6 2}$ & $\mathbf{8 . 1}$ \\
France & 105,557 & 197,730 & 8.1 \\
China & 27,449 & 59,031 & 11.4 \\
\hline
\end{tabular}

Incomes are in US Dollars calculated based on the market exchange rate and refer to earnings in 2014

Bolded text signifies the country in which the current research was conducted

about how the One Percent exercise their power depend upon claims about their political attitudes as a group (see Gilens 2005). We aim to fill these gaps by comparing the political attitudes of the One Percent in New Zealand to the general population, using a large, representative sample $(N=14,650$; see Table 1 for a comparison between New Zealand's One Percent and the One Percent in other major economies).

Several theories in social psychology propose that the political attitudes of (particularly) members of advantaged groups align with their own group's interests-i.e., they hold beliefs about the political and economic system that help maintain their own dominance within it (Sidanius and Pratto 1999; Rubin and Hewstone 2004). These perspectives would suggest that, having benefitted from the current political and economic systems, the One Percent would be more supportive of these systems and more opposed to policies that threaten their economic power.

On the other hand, there appears to be an increasing acknowledgement of the problem of inequality among the class of economic elites (Buffet 2011; WEF 2015), which undermines the common-sense notion that the One Percent will inevitably hold political beliefs that benefit their own group at the expense of everyone else. Indeed, System Justification Theory proposes that often it is not the most advantaged, but the most disadvantaged who show the strongest support for unequal systems (Jost et al. 2003; cf. Brandt 2013). Therefore, more data is needed about how much the political attitudes of the One Percent differ from the general population and in which direction.

The extant literature is sparse and difficult to interpret. For example, an analysis of 397 individuals falling in the top one percent of income earners in the US found that higher proportion identified as 'Republican' (57\%) compared to the rest of the population (44\%), while a similar proportion identified as 'Conservative' (39\% versus 40\%; Saad 2011a). Another study, involving 83 of Chicago's wealthiest one percent, found that a higher percentage supported economically conservative policies than the percentages of people who supported such policies in a different general population survey (Page et al. 2013). However, both these studies are problematic. The former includes rather crude measures of political attitudes, while the latter is extremely limited in both its sampling frame and sample size. We aim to improve on these findings by testing more specific political attitudes in a representative national sample in New Zealand that includes a large number of 'One Percenters'.

This large, representative sample also allows us to compare the subjective wellbeing of the One Percent to the general population-another issue which has important implications 
for societal inequality but suffers from a scarce data and contradictory theoretical accounts. One strand of research that falls under the rubric of "Livability Theory" (see Veenhoven 1995) suggests that income does not predict wellbeing for people who are already fairly well-off. Evidence for this idea comes from cross-national studies showing no increases in national-level wellbeing once per capita income rises beyond USD 10,000 (Frey and Stutzer 2002; Helliwell 2003). Similarly, for people living in wealthy nations, large changes in national income across time have not been found to produce corresponding increases in wellbeing (Easterlin 1995; Oswald 1997).

On the other hand, robust effects of income on wellbeing have been found at the individual level, even at the upper ends of the income distribution in wealthy nations (see Easterlin 2001 for a review). However, the national surveys used to investigate these effects usually measure income using broad categories, the uppermost of which are not extreme enough to capture subjective wellbeing among the One Percent (e.g., Kahneman and Deaton 2010). A notable exception is a study by Diener et al. (1985b) that sampled super-rich individuals from the Forbes' list of wealthiest Americans and found that they were more satisfied with their lives than a matched control group from the same geographical area.

Understanding whether the One Percent do indeed have higher wellbeing than everyone else is particularly important because there are pervasive beliefs in society that belonging to high-status groups comes with certain downsides (Jost et al. 2005) - e.g., the wealthy incur a psychological cost for their wealth. These beliefs can function to legitimize inequality, making it harder to reduce it (Kay and Jost 2003). Therefore, in addition to examining the political attitudes of the One Percent, the present study will also examine their subjective wellbeing.

Thus, we aim to shed light on both the top-down and bottom-up processes that maintain inequality in society by examining, in the New Zealand context, whether (a) the elites have political preferences that exacerbate inequality, and (b) the beliefs about the elites held by the general public are accurate, or merely myths that further entrench existing inequality. We are able to fulfill these aims better than previous national surveys because instead of asking people to place themselves in one of a limited number of income categories, we asked them to report their income in an open-ended format, allowing us to better capture the extremes of the income distribution.

Specifically, in the political domain, we compare levels of three types of political attitudes that are relevant to the societal discourse on inequality-belief in the legitimacy of the political system, belief in the legitimacy of the economic system, and opposition to redistributive taxation-between the "One Percent", the "Rest of the Top 5\%" and "Everyone Else" (see Table 2 for sample demopgrahics for these three income categories). We included people who fall in the Top $5 \%$ of the income distribution (while not reaching the level of the One Percent) to as an additional comparison group to see whether those on extremely high incomes differed from those who were merely on very high incomes. Despite the contradictory theoretical accounts (e.g. Jost et al. 2003; cf. Sidanius and Pratto 1999), the sparse evidence that currently exists (e.g., Page et al. 2013) points to the One Percent holding political preferences that exacerbate inequality. Based on this, we predict that the One Percent will show higher levels of belief in the legitimacy of the political and economic systems, as well higher opposition to redistributive taxation than the "Rest of the Top 5\%" and "Everyone Else".

In the wellbeing domain, we compare levels of three indices of subjective wellbeinglife satisfaction, self esteem and felt belongingness-between the same three income categories. Despite the fact that prior studies have not been able to isolate the extreme upper end of the income distribution, the pattern of effects of income on wellbeing (e.g., Diener 
Table 2 Sample demographics for the three income categories being compared in the present study

\begin{tabular}{llll}
\hline & One Percent & Rest of the Top 5\% & Everyone else \\
\hline Income threshold (NZD) & $\geq 200,000$ & $106,000-199,000$ & $0-105,000$ \\
Mean income (NZD) & 312,400 & 135,858 & 43,666 \\
Median income (NZD) & 250,000 & 130,000 & 42,000 \\
Mean age (years) & 51.37 & 50.00 & 48.93 \\
Gender (\% women) & $23.0 \%$ & $35.0 \%$ & $66.4 \%$ \\
Education (\% university graduates) & $41.6 \%$ & $34.0 \%$ & $41.1 \%$ \\
Ethnicity & & & \\
$\%$ European & $90.0 \%$ & $88.4 \%$ & $80.5 \%$ \\
$\%$ Maori & $6.6 \%$ & $8.5 \%$ & $12.6 \%$ \\
$\%$ Pacific Islanders & $.6 \%$ & $1.0 \%$ & $2.7 \%$ \\
$\%$ Asian & $2.8 \%$ & $2.1 \%$ & $4.1 \%$ \\
\hline
\end{tabular}

et al. 1985a, b) suggest that people on higher incomes experience greater wellbeing. Based on this, we predict that the One Percent will show higher life satisfaction, self esteem, and belongingness than the "Rest of the Top 5\%" and "Everyone Else".

\section{Method}

\subsection{Procedure}

The NZAVS is an ongoing 20-year longitudinal national probability study of social attitudes, personality, and health outcomes that started in 2009. Each year, participants are posted a copy of the questionnaire, with a second postal follow-up 2 months later. Participants who provided an email address were also emailed and invited to complete an online version if they preferred. Detailed information about the sampling procedures, overall retention rates, demographic characteristics, and items included in the NZAVS questionnaires are provided on the NZAVS website (Sibley 2015). The NZAVS performs well in terms of representativeness (for more information see Sibley 2014), but oversamples women by about $10 \%$, under-samples people in their $20 \mathrm{~s}$, and those of Asian ethnicity. Here, we draw data from Time $6(2014 / 15)$ of the NZAVS, which contained responses from 15,822 participants. We chose Time 6 because it had the largest sample size of any wave for which all target measures were available.

\subsection{Measures}

\subsubsection{Income}

Personal income was measured using an open-ended item that asked "Please estimate your own personal earnings (before tax) for the year 2014". For the purposes of the current analysis we divided people into three groups based on their self-reported personal income: The "One Percent", the "Rest of the Top 5\%" and "Everyone else" (i.e. the bottom $95 \%$ of the income distribution). The income thresholds for being categorized into each group were determined using data from Inland Revenue Department, which provides the 
income distribution for approximately 3.6 million taxpayers in New Zealand year on year from 2001 to 2014 (IRD 2015). Using data from 2014 (which pertained to income earned between April 1, 2013 and March 31, 2014) we determined that the One Percent of income earners were those who earned NZD 200,000 or more and the Top 5\% of income earners were those who earned NZD 106,000 or more in the preceding year.

\subsubsection{Political Attitudes}

Perceived legitimacy of the political system was measured using four items adapted from Kay and Jost's (2003) General System Justification scale. This 8-item scale is the most widely used scale for measuring political legitimacy (see Jost et al. 2012 for a review). However, the scale has not been evaluated for its psychometric properties, and so there was no clear empirical criterion for selecting the smaller number of items to include in our short scale. Thus, we adapted the four items from the original scale that were most applicable to the New Zealand context: "In general, the New Zealand political system operates as it should", "In general, I find New Zealand society to be fair", "Everyone has a fair shot at wealth and happiness in New Zealand" and "Most of New Zealand's policies serve the greater good". This selection of items showed good internal reliability $(\alpha=.75)$ and have also been used in past research demonstrating good construct validity (Osborne and Sibley 2013; Vargas-Salfate et al. 2018a, b).

Perceived legitimacy of the economic system was measured one item taken from the Economic System Justification scale developed by Jost and Thompson (2000). As with political legitimacy, there is no well validated scale for measuring economic legitimacy, and so selecting an item from an existing scale was the best remaining option. Although the items on Jost and Thompson's (2000) original scale are rather heterogenous, the social psychological literature on how people appraise the legitimacy of outcomes suggests that people can either make internal or external attributions for outcomes (e.g., Hewstone 1989; Jost and Major 2001). In the economic domain, this means making internal or external attributions for the distribution of economic resources-i.e., that economic outcomes reflect either people's own merits, or instead, have structural causes (see Bullock et al. 2003). We selected the one item from the Economic System Justification scale that we felt best captured this type of attributional appraisal of economic outcomes: "Economic positions are legitimate reflections of people's achievements".

Support for redistributive taxation was measured by asking for people's degree of support versus opposition to the following policy: "Redistributing money and wealth more evenly among a larger percentage of the people in New Zealand through heavy taxes on the rich". This item was adapted from a Gallup Poll question that has been administered to thousands of Americans every year from 1999 to 2011 (Saad 2011b).

\subsubsection{Subjective Wellbeing}

Life satisfaction was measured using the following two items: "I am satisfied with my life" and "In most ways my life is close to ideal" $(r=.70)$. These items were selected by taking the two items that showed the highest factor loadings on the latent construct from the 5-item Satisfaction with Life Scale as reported in the scale-validation study by Diener et al. (1985a). This short version of the scale has been used extensively in prior research, 
demonstrating excellent construct validity (Girme et al. 2016; Greaves et al. 2017; Osborne et al. 2016; Sibley and Bulbulia 2015; Stronge et al. 2016a, b).

Self-esteem was measured using the following three items: "On the whole am satisfied with myself", "Take a positive attitude toward myself" and "Am inclined to feel that I am a failure". These items were selected by taking the two highest-loading pro-trait items and the highest-loading con-trait item from Rosenberg's (1965) self-esteem scale as reported in a large-scale principal components analysis conducted on a New Zealand sample (in addition to samples from 52 other countries; Schmitt and Allik 2005). This three-item version of the scale showed excellent internal reliability $(\alpha=.80)$. Moreover, the construct validity of this scale can be established by the fact that it has been used extensively in prior research, yielding the expected correlations with other theoretically relevant constructs (e.g., Greaves et al. 2017; Lee and Sibley 2017; Manuela and Sibley 2014; Matika et al. 2017; Osborne et al. 2015; Stronge et al. 2016a; Waddell et al. in press).

Belongingness was measured using the following three items: "Know that people in my life accept and value me", "Feel like an outsider" and "Know that people around me share my attitudes and beliefs". Selecting items for the belongingness scale was less straightforward than the other two wellbeing constructs because the study in which the scale was first presented did not provide factor loadings for the individual items on the scale (Cutrona and Russell 1987). However, a subsequent validation study by Mancini and Blieszner (1992) did provide this information. Based on this analysis, we chose the highest-loading item from the 'social integration' subscale and the highest-loading item from 'reassurance of worth' subscale. In addition we developed a con-trait item that we thought best captured the lack of belongingness connoted by the con-trait items on the original scale (i.e., "I feel like an outsider"). This item was preferred because it captured a more general sense of social exclusion than the con-trait items on the original scale, which were more specific in content (e.g., "There is no one I can turn to for guidance in times of stress"; "Other people do not view me as competent"). This three-item version of the scale showed good internal reliability $(\alpha=.71)$. This scale has also been used in prior research, showing good construct validity (Stronge et al. 2015; Greaves et al. 2017). All dependent variables were rated on scales that ranged from 1 (strongly disagree/strongly oppose) to 7 (strongly agree/ strongly support).

\subsection{Participants}

The participants in this analysis were the approximately 14,600 individuals from the NZAVS Time $6(2014 / 15)$ who had provided information on the relevant measures. This number is approximate because the exact sample size varied for each analysis depending on the number of people who had responded to the items that constituted the dependent variable in each analysis. In all, personal income data was available for 14,648 individuals and therefore it was these individuals who were subsequently categorized into the "One Percent", "Rest of the Top 5\%" and "Everyone Else" groups. Of these, 326 participants (i.e., 2.2\%) fell into the One Percent category, 1170 participants (i.e., 8.0\%) fell into the Rest of the Top 5\% category and the remaining 13,152 participants (i.e., 89.8\%) fell into the Everyone Else category (based on the income thresholds described above). Thus, the NZAVS Time $6(2014 / 15)$ oversampled the Top 1\% and Top 5\% of the income distribution.

As shown in Table 2, in the One Percent category, $77 \%$ were male, $41.6 \%$ had a University degree, and 90\% were New Zealand European (with 6.6\% being Maori, .6\% being Pacific Islanders and $2.8 \%$ being Asian). The mean age of this group 51.37 years 
$(S D=8.87)$. Of the Rest of the Top 5\%, 65\% were male, $34 \%$ had a University degree, and $88.4 \%$ were New Zealand European (with $8.5 \%$ being Maori, $1.0 \%$ being Pacific Islanders and $2.1 \%$ being Asian). The mean age of this group was 50.00 years $(S D=9.35)$. Of Everyone Else, $34.1 \%$ were male, $41.1 \%$ had a University degree, and $80.5 \%$ were New Zealand European (with $12.6 \%$ being Maori, $2.7 \%$ being Pacific Islanders and $4.1 \%$ being Asian). The mean age of this group was 48.93 years $(S D=14.21)$.

\subsection{Analysis Plan}

We propose to conduct six one-way ANOVAs to test for mean differences in the three indices of well-being (Life Satisfaction, Self-Esteem and Belongingness) and the three kinds of political attitudes (Legitimacy of the Political System, Legitimacy of the Economic System and Support for Redistributive Taxation) between the three income categories (i.e. 'the One Percent,' 'the Rest of the Top 5\%' and 'Everyone Else').

\section{Results}

Results of the six one-way ANOVAs are summarized in Fig. 1. Descriptive statistics and correlations between all variables used in these ANOVAs are presented in Table 3. Effects sizes for each mean difference tested are presented in Table 4 . We selected a more conservative critical alpha of $p=.01$ due to the large sample size.

\subsection{Political Attitudes}

\subsubsection{Legitimacy of the Political System}

The one-way ANOVA testing for differences in the perceived legitimacy of the political system between the three income categories was significant $(F(2,14,599)=124.26$, $p<.001)$. Bonferonni post hoc tests revealed that the One Percent $(M=5.11, S D=.98$, $95 \%$ CI $[5.00,5.22])$ perceived the political system to be significantly more legitimate on average than the Rest of the Top 5\% $(M=4.82, S D=1.06,95 \%$ CI $[4.76,4.88], p<.001$, Cohen's $d=.26)$ and Everyone Else $(M=4.41, S D=1.15,95 \%$ CI $[4.39,4.43], p<.001$, Cohen's $d=.62)$. The Rest of the Top 5\% perceived the political system to be more legitimate on average than Everyone Else $(p<.001$, Cohen's $d=.36)$.

\subsubsection{Legitimacy of the Economic System}

The one-way ANOVA testing for differences in the perceived legitimacy of the economic system between the three income categories was significant $(F(2,14,146)=22.90$, $p<.001)$. Bonferonni post hoc tests revealed that the One Percent perceived the economic system to be significantly more legitimate on average $(M=3.89, S D=1.72,95 \%$ CI [3.70, 4.08]) than the Rest of the Top 5\% $(M=3.54, S D=1.67,95 \%$ CI [3.44, 3.63], $p=.002$, 
Legitimacy of the Political System

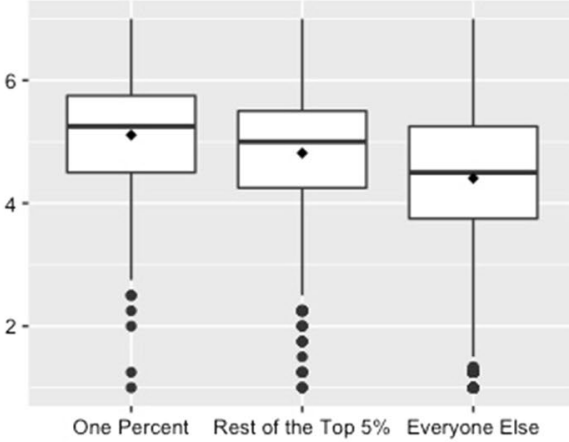

Legitimacy of the Economic System

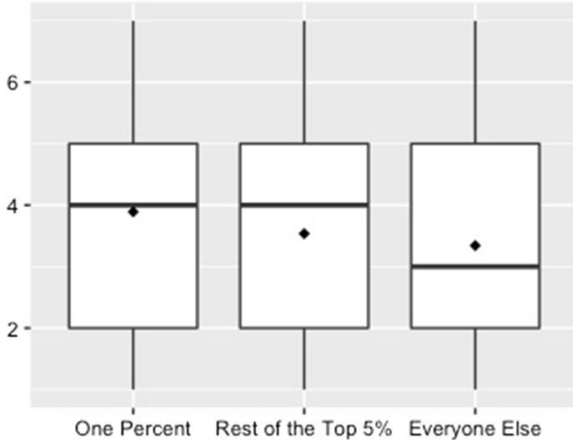

Opposition to Redistributive Taxation

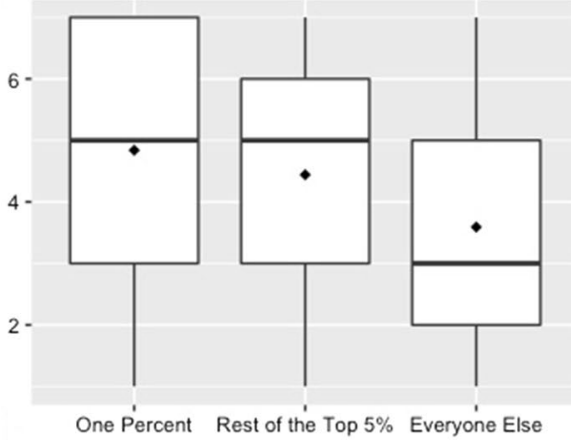

\section{Life Satisfaction}

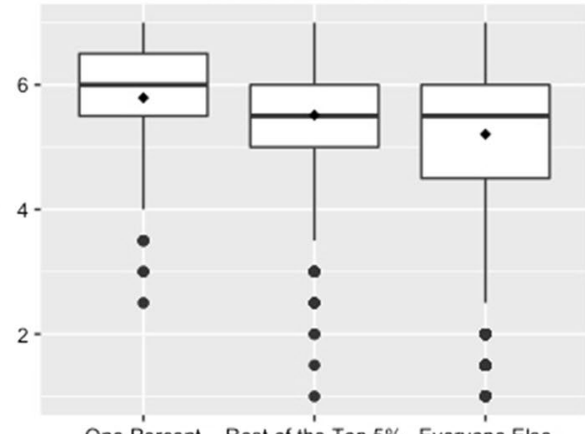

One Percent Rest of the Top 5\% Everyone Else Self Esteem

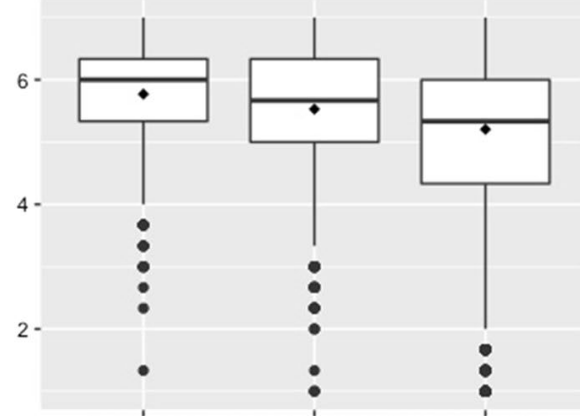

One Percent Rest of the Top 5\% Everyone Else

Belongingness

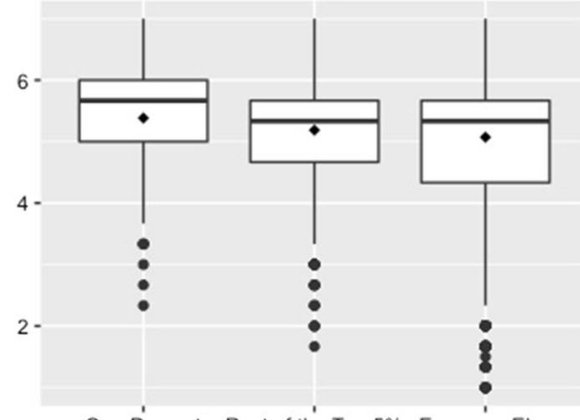

Fig. 1 Boxplots showing the means and distributions of the three types of political attitudes (left panel) and the three subjective wellbeing indicators (right panel) among the One Percent, the Rest of the Top 5\% and Everyone Else

Cohen's $d=.21)$ and Everyone Else $(M=3.37, S D=1.67,95 \%$ CI $[3.31,3.37] p<.001$, Cohen's $d=.33$ ). The Rest of the Top 5\% perceived the economic system to be more legitimate than Everyone Else ( $p=.001$, Cohen's $d=.12)$. 
Table 3 Descriptive statistics and correlations between all variables

\begin{tabular}{llllllll}
\hline & 1 & 2 & 3 & 4 & 5 & 6 & 7 \\
\hline 1. Income (in 1000 s) & - & & & & & \\
2. Legitimacy of the political system & $.13^{*}$ & - & & & & \\
3. Legitimacy of the economic system & $.05^{*}$ & $.42^{*}$ & - & & & & \\
4. Opposition to redistributive taxation & $.14 *$ & $.45^{*}$ & $.32^{*}$ & - & & & \\
5. Life satisfaction & $.11^{*}$ & $.33^{*}$ & $.08^{*}$ & $.14^{*}$ & - & & \\
6. Self esteem & $.10^{*}$ & $.23^{*}$ & $.05^{*}$ & $.08^{*}$ & $.63^{*}$ & - \\
7. Belongingness & $.06^{*}$ & $.22^{*}$ & $.06^{*}$ & $.08^{*}$ & $.52^{*}$ & $.63^{*}$ & - \\
$M$ & 57.37 & 4.45 & 3.36 & 3.62 & 5.24 & 5.25 & 5.09 \\
$S D$ & 71.92 & 1.14 & 1.67 & 2.07 & 1.17 & 1.20 & 1.02 \\
\hline
\end{tabular}

$* p<.01$

Table 4 Effect sizes for the mean differences between the three income categories on all dependent variables

\begin{tabular}{|c|c|c|c|c|}
\hline \multirow[t]{2}{*}{ Dependent variable } & \multirow[t]{2}{*}{ Comparison } & \multirow[t]{2}{*}{ Cohen's $d$} & \multicolumn{2}{|c|}{$95 \% \mathrm{CI}$} \\
\hline & & & low & high \\
\hline \multirow[t]{3}{*}{ Legitimacy of the political system } & One Percent-Rest of the Top 5\% & .26 & .14 & .38 \\
\hline & One Percent-Everyone else & .62 & .51 & .73 \\
\hline & Rest of the Top 5\%-Everyone else & .36 & .30 & .42 \\
\hline \multirow[t]{3}{*}{ Legitimacy of the economic system } & One Percent-Rest of the Top 5\% & .21 & .09 & .34 \\
\hline & One Percent-Everyone else & .33 & .22 & .44 \\
\hline & Rest of the Top 5\%-Everyone else & .12 & .05 & .18 \\
\hline \multirow[t]{3}{*}{ Support for redistributive taxation } & One Percent-Rest of the Top 5\% & .21 & .09 & .34 \\
\hline & One Percent-Everyone else & .66 & .55 & .77 \\
\hline & Rest of the Top 5\%-Everyone else & .45 & .39 & .51 \\
\hline \multirow[t]{3}{*}{ Life satisfaction } & One Percent-Rest of the Top 5\% & .24 & .11 & .36 \\
\hline & One Percent-Everyone else & .50 & .39 & .61 \\
\hline & Rest of the Top 5\%-Everyone else & .26 & .20 & .32 \\
\hline \multirow[t]{3}{*}{ Self esteem } & One Percent-Rest of the Top 5\% & .20 & .08 & .32 \\
\hline & One Percent-Everyone else & .47 & .36 & .58 \\
\hline & Rest of the Top 5\%-Everyone else & .27 & .21 & .33 \\
\hline \multirow[t]{3}{*}{ Belongingness } & One Percent-Rest of the Top 5\% & .19 & .07 & .31 \\
\hline & One Percent-Everyone else & .31 & .20 & .42 \\
\hline & Rest of the Top 5\%-Everyone else & .11 & .05 & .17 \\
\hline
\end{tabular}

\subsubsection{Opposition to Redistributive Taxation}

The one-way ANOVA testing for differences in opposition to redistributive taxation between the three income categories was significant $(\mathrm{F}(2,14,370)=171.13, p<.001)$. Bonferonni post hoc tests revealed that the One Percent were significantly more opposed 
redistributive taxation on average $(M=4.84, S D=1.88,95 \%$ CI $[4.63,5.05])$ than the Rest of the Top 5\% $(M=4.44, S D=1.95,95 \%$ CI $[4.34,4.55], \mathrm{p}=.006$, Cohen's $d=.21)$ and Everyone Else $(M=3.59, S D=1.87,95 \%$ CI [3.56, 3.62], $p<.001$, Cohen's $d=.66)$. The Rest of the Top 5\% were significantly less supportive of redistributive taxation than Everyone Else $(p<.001$, Cohen's $d=.45)$.

\subsection{Subjective Wellbeing}

\subsubsection{Life Satisfaction}

The one-way ANOVA testing for differences in life satisfaction between the three income categories was significant $(\mathrm{F}(2,14216)=71.98, p<.001)$. Bonferonni post hoc tests revealed that the One Percent had significantly higher life satisfaction on average $(M=5.79$, $S D=.86,95 \%$ CI $[5.70,5.88])$ than the Rest of the Top $5 \%(M=5.51, S D=.90,95 \% \mathrm{CI}$ [5.46, 5.56], $p=.001$, Cohen's $d=.24)$ and Everyone Else $(M=5.21, S D=1.20,95 \% \mathrm{CI}$ $[5.19,5.23], p<.001$, Cohen's $d=.50)$. The Rest of the Top 5\% also had significantly higher life satisfaction on average than Everyone Else $(p<.001$, Cohen's $d=.26)$.

\subsubsection{Self-Esteem}

The one-way ANOVA testing for differences in self-esteem between the three income categories was significant $(\mathrm{F}(2,14598)=72.13, p<.001)$. Bonferonni post hoc tests revealed that the One Percent had significantly higher self-esteem on average $(M=5.77, S D=.97$, 95\% CI $[5.66,5.88])$ than the Rest of the Top 5\% $(M=5.53, S D=1.02,95 \%$ CI $[5.47$, 5.59], $p=.004$, Cohen's $d=.20)$ and Everyone Else $(M=5.20, S D=1.21,95 \%$ CI [5.18, 5.22 ], $p<.001$, Cohen's $d=.47$ ). The Rest of the Top 5\% also had significantly higher selfesteem on average than Everyone Else ( $p<.001$, Cohen's $d=.27)$.

\subsubsection{Belongingness}

The one-way ANOVA testing for differences in belongingness between the three income categories was significant $(\mathrm{F}(2,14,598)=21.13, p<.001)$. Bonferonni post hoc tests revealed that the One Percent felt a significantly higher sense of belongingness on average $(M=5.38, S D=.86,95 \%$ CI $[5.29,5.48])$ than the Rest of the Top 5\% $(M=5.19, S D=.89$, $95 \%$ CI $[5.14,5.24], p=.006$, Cohen's $d=.19)$ and Everyone Else $(M=5.07, S D=1.03$, $95 \%$ CI $[5.05,5.09], p<.001$, Cohen's $d=.31)$. The Rest of the Top 5\% also felt a significantly higher sense of belongingness on average than Everyone Else ( $p=.001$, Cohen's $d=.11)$.

\section{Discussion}

The very nature of the group-i.e., small and affluent-makes the One Percent extremely difficult to survey. Huge representative samples are required to capture large enough numbers of One Percenters to enable meaningful analyses. Moreover, the types of national surveys that do have the requisite sample size often do not assess income with enough precision to isolate the One Percent (e.g., Kahneman and Deaton 2010). As a result, we know 
very little about this group, despite the fact that it features prominently in the political discourse of many Western nations. We were able to take a step towards filling this gap in the present study.

We found that One Percent in New Zealand believe more strongly in the legitimacy of the political and economic systems that govern society and express lower support for the inequality-reducing policy of redistributive taxation. These findings are consistent with self- and group-interest theories in psychology, which suggest that people hold political beliefs that align with their desire to advance their own position (e.g., Sidanius and Pratto 1999; Rubin and Hewstone 2004).

These results also provide evidence for a core assumption underlying much of the political discourse about the One Percent. This discourse holds that the concentration of wealth in the hands of the One Percent is corrosive for democracy because they use their political influence to maintain the inequality from which their group benefits (e.g., Stilgitz 2011). This argument appears to be supported by the finding that the types of policies that are implemented in democratic societies correlate more strongly with the policy preferences of economic elites than with those of the general public, especially when the preferences of these groups diverge (Gilens 2005). However, the missing piece in this narrative was whether the political attitudes of the elites do, in fact, diverge from the general public in a direction that would maintain existing inequality. By showing that this is indeed the case, our study helps explain part of the top-down process through which inequality is maintained in free-market democracies.

We are also able to speak to the bottom-up process that maintains inequality-i.e., the legitimizing myths held by the general public that prevent them from challenging inequality (Jost and Hunyady 2005). One of these myths is that no group in society 'has it all'-some people might be poor, but they are happy, and those that are rich are probably unhappy (Kay and Jost 2003). Indeed, beliefs about the unhappy rich are not confined merely to lay opinions. Much of the psychological literature on wellbeing also advances the notion that not only does money not buy happiness (e.g., Diener and Seligman 2004; Csikszentmihalyi 1999), it positively impedes the pursuit of happiness_-inculcating a materialistic ethic that increases stress and relationship conflict, while lowering self-esteem, empathy, intrinsic motivation and sociality (Kasser et al. 2004; Vohs et al. 2008).

Whether or not high-earners face these kinds of tribulations, our findings suggest that they are still able to maintain levels of life-satisfaction, self-esteem and belongingness that, on average, outstrip not just the general population but even the fairly well-off (i.e., the 'Rest of the Top 5\%'). Being in the One Percent seems to benefit people not only economically and politically, but also psychologically. One group can have it all.

\subsection{Limitations}

Here, we operationalized the One Percent category using the distribution of personal income rather than household income or wealth. Wealth inequality in Western nations is even more severe that income inequality, and that therefore, the 'true' elites are not necessarily those on high incomes, but the very wealthy (Piketty 2014). However, as difficult as it is to survey the upper echelons of the income distribution, it is even more difficult to survey those with large fortunes, or even to get them to report their wealth in questionnaires (see Page et al. 2013 for a discussion). Therefore, until data on the wealthy are available we must rely on data from high-earners to understand elite opinion on our societies. We were also unable to use household income because no data exists in New Zealand that is 
fine-grained enough to isolate the Top $1 \%$ of the household-income distribution. However, detailed information on the personal income of every New Zealand taxpayer is available (IRD 2015).

Our findings are also limited by the fact that we have not utilized fully validated measurement instruments for any of the constructs in our analysis. There are two reasons for this. First, the empirical literature on some constructs we sought to measure (e.g., political legitimacy) does not include the of use consistent, validated measurement instruments (see Sengupta 2016; p. 24, 27). Second, constructs for which well-validated scales do exist (e.g., self-esteem) are measured using scales that are too long to be viable for a large-scale, longitudinal, survey designed to measure hundreds of socially-important constructs.

As a result there is considerable variation in the empirical and conceptual strength of the criteria we could implement for each selection being made. However, the fact that we obtained the same pattern of effects across measures for which we had more robust item-selection criteria, and measures for which we had less robust criteria, gives us greater confidence that our findings reflect the true relationship between income and the two second-order constructs in our study-i.e., subjective wellbeing and political attitudes. Moreover, all but one of the measures (i.e., economic legitimacy) have already been used extensively in their current forms demonstrating excellent construct validity (e.g., Manuela and Sibley 2014; Osborne et al. 2016; Osborne and Sibley 2013; Stronge et al. 2015; Saad 2011b).

Nevertheless, there is a need for future research that uses more comprehensive measures to assess the relationships tested here. The need for more research is highlighted by the fact that, despite the limitations of our measures, our analysis provides a more comprehensive picture of the political attitudes and wellbeing of the upper end of the income distribution than existing studies. For example, coarse-grained income measures and a disproportionate focus on one particular dimension of wellbeing (i.e., life-satisfaction; see Diener and Oishi 2000) have resulted in a very limited current understanding of the wellbeing of the One Percent.

The breadth and validity of measurement in the political domain is even more constrained. For example, the only analyses of the political attitudes of the extremely well-off, to date, have used either a single, dichotomous measure of conservative versus liberal self-identification (Saad 2011a), or nominal scales measuring support for specific policy proposals (Page et al. 2013). Therefore, the present study represents an important incremental step in our understanding of the political psychology of an important but under-researched group.

Finally, the fact that our data come from one country-New Zealand-might limit the broader relevance of our findings. However, New Zealand is extremely similar to other Western nations in which debates about inequality and the One Percent are currently raging. For example, it has a highly developed free-market economy (Miller and Kim 2015), robust democratic institutions (EIU 2016), and a recent history of neoliberal economic policies that have been blamed for rising inequality since the 1980s, in a similar way to Thatcherism in the UK and Reagonomics in the US (Marcetic 2017).

Moreover, as one of the most unequal countries in the OECD (OECD 2017), New Zealand's One Percent represent the same class of economic elites that are referred to in the political discourse of other capitalist societies (and accrue very similar sociopolitical advantages as a result of this elite status; see Table 1). Therefore, to the extent that the differences in political attitudes and wellbeing reported here are a function of group status, there is no reason to expect a substantively different pattern of results in other Western countries. 


\section{Conclusion}

For the first time, our study has documented how the political attitudes and subjective wellbeing of the One Percent differ from the rest of the population. We found that, in New Zealand, this group shows higher inequality-enhancing political preferences and higher subjective wellbeing than the general public. Thus, we have taken the first step towards understanding the psychology of societal elites, and consequently, the processes by which inequality is maintained in free-market democracies.

Acknowledgements The New Zealand Attitudes and Values Study is supported by a grant from the Templeton Religion Trust (TRT0196). This study is also supported by a Marie Skłodowska Curie Individual Fellowship awarded to Nikhil Sengupta (ID: 703316).

Open Access This article is distributed under the terms of the Creative Commons Attribution 4.0 International License (http://creativecommons.org/licenses/by/4.0/), which permits unrestricted use, distribution, and reproduction in any medium, provided you give appropriate credit to the original author(s) and the source, provide a link to the Creative Commons license, and indicate if changes were made.

\section{References}

Brandt, M. J. (2013). Do the disadvantaged legitimize the social system? A large-scale test of the statuslegitimacy hypothesis. Journal of Personality and Social Psychology, 104, 765-785. https://doi. org/10.1037/a0031751.

Buffet, W. E. (2011). Stop coddling the Super-rich. The New York Times. Retrieved from: http://www.nytim es.com/2011/08/15/opinion/stop-coddling-the-super-rich.html. Accessed 10 July 2018.

Bullock, H. E., Williams, W. R., \& Limbert, W. M. (2003). Predicting support for welfare policies: The impact of attributions and beliefs about inequality. Journal of Poverty, 7, 35-56.

Carroll, L. \& Kertscher, T. (2016). At DNC, Bernie Sanders repeats claim that top one-tenth of $1 \%$ owns as much wealth as bottom $90 \%$. Politifact.com. Retrieved from: http://www.politifact.com/truth-o-meter /statements/2016/jul/26/bernie-s/dnc-bernie-sanders-repeats-claim-top-one-tenth-1-o/. Accessed 10 July 2018.

Csikszentmihalyi, M. (1999). If we are so rich, why aren't we happy? American Psychologist, 54, 821. https ://doi.org/10.1037/0003-066X.54.10.821.

Cutrona, C. E., \& Russell, D. W. (1987). The provisions of social relationships and adaptation to stress. Advances in Personal Relationships, 1, 37-67.

Diener, E., Emmons, R. A., Larsen, R. J., \& Griffin, S. (1985a). The satisfaction with life scale. Psychological Assessment, 49, 71-75.

Diener, E., Horwitz, J., \& Emmons, R. A. (1985b). Happiness of the very wealthy. Social Indicators Research, 16, 263-274. https://doi.org/10.1007/BF00415126.

Diener, E., \& Oishi, S. (2000). Money and happiness: Income and subjective well-being across nations. In E. Diener, \& E. M. Suh (Eds.), Culture and Subjective Well-Being, pp. 185-218.

Diener, E., \& Seligman, M. E. (2004). Beyond money: Toward an economy of well-being. Psychological Science in the Public Interest, 5, 1-31. https://doi.org/10.1111/j.0963-7214.2004.00501001.x.

Easterlin, R. A. (1995). Will raising the incomes of all increase the happiness of all? Journal of Economic Behavior \& Organization, 27, 35-47. https://doi.org/10.1016/0167-2681(95)00003-B.

Easterlin, R. A. (2001). Income and happiness: Towards a unified theory. The Economic Journal, 111, 465484. https://doi.org/10.1111/1468-0297.00646.

EIU. (2016). The economist intelligence unit's 2016 democracy index. Retrieved from: https://infographi cs.economist.com/2017/DemocracyIndex/. Accessed 10 July 2018.

Frey, B. S., \& Stutzer, A. (2002). What can economists learn from happiness research? Journal of Economic Literature, 40, 402-435. https://doi.org/10.3929/ethz-a-004374069.

Gilens, M. (2005). Inequality and democratic responsiveness. Public Opinion Quarterly, 69, 778-796. https ://doi.org/10.1093/poq/nfi058. 
Girme, Y., Overall, N. C., Faingataa, S., \& Sibley, C. G. (2016). Happily single: The link between relationship status and wellbeing depends on avoidance and approach social goals. Social Psychology and Personality Science, 7, 122-130.

Greaves, L. M., Barlow, F. K., Huang, Y., Stronge, S., Fraser, G., \& Sibley, C. G. (2017). Asexual identity in a national sample: Demographics, wellbeing, and health. Archives of Sexual Behavior, 46, 2417-2427.

Helliwell, J. F. (2003). How's life? Combining individual and national variables to explain subjective wellbeing. Economic Modelling, 20, 331-360. https://doi.org/10.1016/S0264-9993(02)00057-3.

Hewstone, M. (1989). Causal attribution: From cognitive processes to collective beliefs. Oxford: Blackwell.

IRD. (2015). Income distributions of individual customers 2001 to 2014. Retrieved from: http://www.ird. govt.nz/aboutir/external-stats/revenue-refunds/income-distrib-individual-customers/income-distribindivid-customers.html. Accessed 10 July 2018.

Jost, J. T., \& Hunyady, O. (2005). Antecedents and consequences of system-justifying ideologies. Current Directions in Psychological Science, 14, 260-265. https://doi.org/10.1111/j.0963-7214.2005.00377.x.

Jost, J. T., Kivetz, Y., Rubini, M., Guermandi, G., \& Mosso, C. (2005). System-justifying functions of complementary regional and ethnic stereotypes: Cross-national evidence. Social Justice Research, 18, 305333. https://doi.org/10.1007/s11211-005-6827-z.

Jost, J. T., \& Major, B. (Eds.). (2001). The psychology of legitimacy: Emerging perspectives on ideology, justice, and intergroup relations. Cambridge: Cambridge University Press.

Jost, J. T., Pelham, B. W., Sheldon, O., \& Ni Sullivan, B. (2003). Social inequality and the reduction of ideological dissonance on behalf of the system: Evidence of enhanced system justification among the disadvantaged. European Journal of Social Psychology, 33, 13-36. https://doi.org/10.1002/ ejsp. 127.

Jost, J. T., \& Thompson, E. P. (2000). Group-based dominance and opposition to equality as independent predictors of self-esteem, ethnocentrism, and social policy attitudes among African Americans and European Americans. Journal of Experimental Social Psychology, 36, 209-232. https://doi. org/10.1006/jesp.1999.1403.

Jost, J. T., \& van der Toorn, J. (2012). System justification theory. In P. Lange, A. W. Kruglanski, \& E. T. Higgins (Eds.), Handbook of theories of social psychology (pp. 313-338). Los Angeles, CA: Sage.

Kahneman, D., \& Deaton, A. (2010). High income improves evaluation of life but not emotional well-being. Proceedings of the National Academy of Sciences, 107, 16489-16493. https://doi. org/10.1073/pnas.1011492107.

Kasser, T., Ryan, R. M., Couchman, C. E., \& Sheldon, K. M. (2004). Materialistic values: Their causes and consequences. In T. Kasser \& A. D. Kanner (Eds.), Psychology and consumer culture: The struggle for a good life in a materialistic world (pp. 11-28). Washington, DC: American Psychological Association.

Kay, A. C., \& Jost, J. T. (2003). Complementary justice: Effects of "poor but happy" and "poor but honest" stereotype exemplars on system justification and implicit activation of the justice motive. Journal of Personality and Social Psychology, 85, 823-837. https://doi.org/10.1037/0022-3514.85.5.823.

Lee, C. H., \& Sibley, C. G. (2017). Demographic and psychological correlates of satisfaction with healthcare access in New Zealand. The New Zealand Medical Journal, 130, 11-24.

Mancini, J. A., \& Blieszner, R. (1992). Social provisions in adulthood: Concept and measurement in close relationships. Journal of Gerontology, 47, 14-20.

Manuela, S., \& Sibley, C. G. (2014). Why do Pacific people with multiple ethnic affiliations have poorer subjective wellbeing? Negative ingroup affect mediates the identity tension effect. Social Indicators Research, 115, 319-336.

Marcetic, B. (2017). New Zealand's Neoliberal Drift. Jacobin Magazine. Retrieved from: https://www. jacobinmag.com/2017/03/new-zealand-neoliberalism-inequality-welfare-state-tax-haven/. Accessed 10 July 2018.

Matika, C. M., Manuela, S., Muriwai, E., Houkamau, C. A., \& Sibley, C. G. (2017). Cultural efficacy predicts increased self-esteem for Maori: The mediating effect of rumination. New Zealand Journal of Psychology, 46(3), 176-185.

Miller, T., \& Kim, A. B. (2015). 2015 index of economic freedom. Washington DC: The Heritage Foundation.

Occupy Wall Street. (2011). About Us. Retrieved from http://occupywallst.org/about/. Accessed 10 July 2018.

OECD. (2017). Income inequality. Retrieved from: https://data.oecd.org/inequality/income-inequality.htm. Accessed 10 July 2018.

Osborne, D., Milojev, P., \& Sibley, C. G. (2016). Examining the indirect effects of religious orientations on well-being through personal locus of control. European Journal of Social Psychology, 46, 492-505. 
Osborne, D., \& Sibley, C. G. (2013). After the disaster: Using the Big-Five to predict changes in mental health among survivors of the 2011 Christchurch Earthquake. Disaster Prevention and Management, 22, 456-466.

Osborne, D., Sibley, C. G., \& Sengupta, N. K. (2015). Income and neighbourhood-level inequality predict self-esteem and ethnic identity centrality through individual- and group-based relative deprivation: A multilevel path analysis. European Journal of Social Psychology, 45, 368-377.

Oswald, A. J. (1997). Happiness and economic performance. The Economic Journal, 107, 1815-1831. https://doi.org/10.1111/j.1468-0297.1997.tb00085.x.

Page, B., Bartels, L., \& Seawright, J. (2013). Democracy and the policy preferences of wealthy Americans. Perspectives on Politics, 11, 51-73. https://doi.org/10.1017/S153759271200360X.

Piketty, T. (2014). Capital in the twenty-first century. Cambridge, MA: Belknap Press.

Rosenberg, M. (1965). Society and the adolescent self-image. Princeton, NJ: Princeton University Press.

Rubin, M., \& Hewstone, M. (2004). Social identity, system justification, and social dominance: Commentary on Reicher, Jost et al., and Sidanius et al. Political Psychology, 25, 823-844. https://doi. org/10.1111/j.1467-9221.2004.00400.x.

Saad, L. (2011a). The "1\%" is more Republican but not more Conservative. Gallup. Retrieved from: http:// www.gallup.com/poll/151310/U.S.-Republican-Not-Conservative.aspx. Accessed 10 July 2018.

Saad, L. (2011b). Americans Divided on Taxing the Rich to Redistribute Wealth. Gallup. Retrieved from: https://news.gallup.com/poll/147881/Americans-Divided-Taxing-Rich-Redistribute-Wealth.aspx. Accessed 10 July 2018.

Schmitt, D. P., \& Allik, J. (2005). Simultaneous administration of the Rosenberg Self-Esteem Scale in 53 nations: exploring the universal and culture-specific features of global self-esteem. Journal of Personality and Social Psychology, 89, 623.

Sengupta, N. K. (2016). Antecedents and consequences of system justification among the disadvantaged. Unpublished $\mathrm{PhD}$ thesis. Available at: https://researchspace.auckland.ac.nz/bitstream/handl e/2292/30906/whole.pdf?sequence=2. Accessed 10 July 2018.

Sibley, C. G. (2014). Comparison of demographics in the NZAVS and New Zealand census (NZAVS Technical Documents, e22). Retrieved from https://cdn.auckland.ac.nz/assets/psych/about/our-research/nzavs /NZAVSTechnicalDocuments/NZAVS-Technical-Documents-e22-Comparison-Demographic-Propo rtions.pdf. Accessed 10 July 2018.

Sibley, C. G. (2015). Sampling procedure and sample details for the New Zealand Attitudes and Values Study (NZAVS Technical Documents, e01). Retrieved from https://cdn.auckland.ac.nz/assets/psych/ about/our-research/nzavs/NZAVSTechnicalDocuments/NZAVS-Technical-Documents-e01-SamplingProcedure-and-Sample-Details.pdf. Accessed 10 July 2018.

Sibley, C. G., \& Bulbulia, J. (2015). Charity explains differences in life satisfaction between religious and secular New Zealanders. Religion, Brain and Behaviour, 5, 91-100.

Sidanius, J., \& Pratto, F. (1999). Social dominance: An intergroup theory of social hierarchy and oppression. Cambridge: Cambridge University Press.

Stilgitz, J. E. (2011). Of the $1 \%$, by the $1 \%$, for the $1 \%$. Vanity Fair. Retrieved from: http://www.vanityfair .com/news/2011/05/top-one-percent-201105. Accessed 10 July 2018.

Stronge, S., Cichocka, A., \& Sibley, C. G. (2016a). Narcissistic self-esteem or optimal self-esteem? A latent profile analysis of self-esteem and psychological entitlement. Journal of Research in Personality, 63, 102-110.

Stronge, S., Greaves, L. M., Milojev, P., West-Newman, T., Barlow, F. K., \& Sibley, C. G. (2015). Facebook is linked to body dissatisfaction: Comparing users and non-users. Sex Roles, 73, 200-213.

Stronge, S., Sengupta, N. K., Barlow, F. K., Osborne, D., Houkamau, C. A., \& Sibley, C. G. (2016b). Perceived discrimination predicts increased support for political rights and life satisfaction mediated by ethnic identity: A longitudinal analysis. Cultural Diversity and Ethnic Minority Psychology, 22, 359-368.

The Equality Trust. (2017). The scale of economic inequality in the UK. https://www.equalitytrust.org.uk/ scale-economic-inequality-uk. Accessed 10 July 2018.

Vargas-Salfate, S., Paez, D., Khan, S. S., Liu, J. H., \& Gil de Zúñiga, H. (2018a). System justification enhances well-being: A longitudinal analysis of the palliative function of system justification in 18 countries. British Journal of Social Psychology, 57(3), 567-590. https://doi.org/10.1111/bjso.12254.

Vargas-Salfate, S., Paez, D., Liu, J. H., Pratto, F., \& Gil de Zúñiga, H. (2018b). A comparison of social dominance theory and system justification: The role of social status in 19 nations. Personality and Social Psychology Bulletin, 44(7), 1060-1076. https://doi.org/10.1177/0146167218757455.

Veenhoven, R. (1995). The cross-national pattern of happiness: Test of predictions implied in three theories of happiness. Social Indicators Research, 34, 33-68. 
Vohs, K. D., Mead, N. L., \& Goode, M. R. (2008). Merely activating the concept of money changes personal and interpersonal behavior. Current Directions in Psychological Science, 17, 208-212. https:// doi.org/10.1111/j.1467-8721.2008.00576.x.

Waddell, N., Sibley, C. G., \& Osborne, D. (in press). Better off alone? Ambivalent sexism moderates the association between relationship status and life satisfaction. Sex Roles.

World Economic Forum. (2015). Outlook on the Global Agenda: 2015. Retrieved from: http://reports. wefor um.org/outlook-global-agenda-2015. Accessed 10 July 2018.

World Inequality Database. (2018). World view. Retrieved from: http://wid.world/world. Accessed 10 July 2018. 